\title{
Giant pericallosal artery aneurysm - Literature review and report of a rare case
}

\author{
José Fernando Guedes Corrêa', Ari Boulanger Sucussel Junior', \\ Rogério Martins Pires Amorim³, Lucas Santos Loiola4, Maristella Reis ${ }^{5}$, Raquel Megali ${ }^{6}$
}

Hospital Universitário Gaffrée e Guinle da Escola de Medicina e Cirurgia da Universidade Federal do Estado do Rio de Janeiro (Unirio), Rio de Janeiro, RJ, Brasil

\section{ABSTRACT}

Giant pericallosal artery aneurysms are extremely rare. Aneurismatic lesions involving this artery are usually small, tend to early bleeding and might be associated with other lesions. Differential diagnosis of giant aneurysms are not easy and includes tumoral, infectious and vascular mass effect lesions. We report a case of a giant and partially thrombosed left pericallosal artery aneurysm. A 58-year-old man, presented with progressive headaches, seizures and speech alterations initially misdiagnosed as a falx cerebri meningioma. As clinical status continue to worsen, magnetic resonance imaging and digital cerebral angiography were performed and a vascular etiology was considered. The patient was then referred to our hospital for surgical treatment. The peculiarity of this case concerns the difficulty of surgical treatment once the surgeon was not able to obtain control of the afferent artery and the aneurysm neck could not be visualized. Also, the aneurysm adhered to the medial surfaces of the frontal lobes and covered the anterior cerebral arteries. Treatment by means of microsurgical thrombectomy, clipping and resection of the lesion was successfully performed. Microsurgical treatment may provide good results when carefully planned with the help of imaging studies of the lesion. It is essential to keep in mind that flexible approach is of great importance when dealing with giant aneurysmatic lesions of pericallosal artery due to its variety of intraoperative presentation.

\section{KEYWORDS}

Intracranial aneurysm, corpus callosum, cerebral arteries.

\section{RESUMO}

Aneurisma gigante de artéria pericalosa - Revisão da literatura e relato de um caso raro

Aneurismas gigantes da artéria pericalosa são raros. Lesões aneurismáticas acometendo essa artéria são, geralmente, pequenas, tendem a sangrar precocemente e associam-se a outras lesões. O diagnóstico diferencial dos aneurismas gigantes é complexo, uma vez que inclui diversas lesões que cursam com efeito de massa, entre elas, as tumorais, infecciosas e vasculares. Relatamos o caso de um aneurisma gigante, parcialmente trombosado, acometendo a artéria pericalosa esquerda. Tratase de um paciente de 58 anos de idade, sexo masculino, apresentando quadro de cefaleia, crises convulsivas e alterações na fala. O achado de uma massa inter-hemisférica de característica hiperdensa à tomografia computadorizada de crânio levou ao diagnóstico errôneo de meningioma da foice cerebral. Uma vez que o quadro clínico do paciente continuou a piorar, optou-se por submetê-lo à ressonância nuclear magnética e à angiografia cerebral digital. A hipótese de etiologia vascular foi então aventada. O paciente foi encaminhado ao nosso serviço para ser submetido a tratamento cirúrgico. A peculiaridade desse caso deve-se à dificuldade de acesso à artéria aferente e de visualização do colo para controle da lesão. Além disso, o aneurisma encontrava-se aderido às faces mediais dos lobos frontais e cobria as artérias cerebrais anteriores. O tratamento cirúrgico por meio de trombectomia microcirúrgica, clipagem e ressecção da lesão pôde ser realizado com sucesso. O tratamento microcirúrgico, quando cuidadosamente planejado por meio de exames de imagem, pode viabilizar a obtenção de resultados satisfatórios. No entanto, deve-se atentar para o fato de que lesões aneurismáticas gigantes de artéria pericalosa podem se apresentar de diversas formas durante o ato operatório, sendo, portanto, essencial uma abordagem flexível, adaptada às peculiaridades de cada lesão.

\section{PALAVRAS-CHAVE}

Aneurisma intracraniano, corpo caloso, artérias cerebrais.

\footnotetext{
1 Neurocirurgião chefe da Divisão de Neurocirurgia do Hospital Universitário Gaffrée e Guinle (HUGG), Rio de Janeiro, RJ, Brasil.

2 Neurocirurgião da Fundação Educacional Serra do Órgãos, Rio de Janeiro, RJ, Brasil.

3 Neurocirurgião da Divisão de Neurocirurgia do HUGG, Rio de Janeiro, RJ, Brasil.

4 Residente de Neurocirurgia do HUGG, Rio de Janeiro, RJ, Brasil.

5 Médica do Serviço de Neurocirurgia do Hospital Estadual Getúlio Vargas, Rio de Janeiro, RJ, Brasil.

6 Médica da Divisão de Neurocirurgia do HUGG, Hospital Estadual Getúlio Vargas, Rio de Janeiro, RJ, Brasil.
} 


\section{Introduction}

Pericallosal artery aneurysms (PAA) are rare lesions. ${ }^{1-5}$ They account for less than $5 \%$ of all saccular intracranial aneurysms, ${ }^{2,5-8}$ usually have small size $e^{1,2,5,9}$ and are frequently associated with multiple lesions. ${ }^{1,3,5}$ Giant pericallosal artery aneurysms are even more uncommon and may present with subarachnoid hemorrhage (SAH), mass effect, distal embolization or acute swelling after rapid and massive intraluminal thrombosis., ${ }^{2,3,10,11}$

We present a case of a 58-year-old man with a giant and partially thrombosed left PAA, which, to the best of our knowledge, is the twenty-eighth case published in the English language literature. ${ }^{12}$

\section{Materials and method}

A 58-year-old Afro-Brazilian otherwise healthy man presented with a 2 -year history of progressive headaches, seizures and speech alterations at another hospital. The patient was submitted to a head computed tomography (CT) scan, which showed a $4 \mathrm{~cm}$ hyperdense frontal interhemispheric lesion with contrast enhancement (Figure 1). The lesion was initially diagnosed as a bilateral falx cerebri meningioma compressing the medial surface of both frontal lobes. At the occasion, the patient refused further diagnostic investigation.

Ten months after the first CT scan, a magnetic resonance imaging (MRI) (Figure 2A) was performed due to the patient's clinical deterioration and the development of new signs and symptoms such as: confusion, paraparesia and bilateral Babinski sign. This exam showed that the lesion had increased to nearly $6 \mathrm{~cm}$. The alternative diagnosis of a giant intracranial aneurysm was then considered. Angio-magnetic resonance imaging (angio-MRI) (Figure 2B) and four-vessel digital cerebral angiography (DCA) (Figure 2C) confirmed the

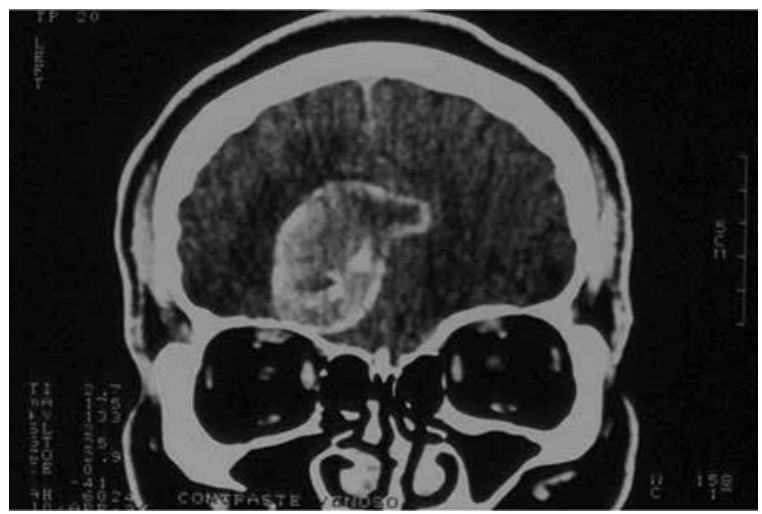

Figure 1 - Coronal CT-scan showing left frontal hyperdense mass lesion crossing the mid line. vascular origin of the lesion (left pericallosal artery) and showed mass effect over both frontal lobes. These exams also revealed that the aneurysm was almost completely thrombosed. There was no evidence of other intracranial lesions. Since clinical status continued to worsen, the patient was referred for evaluation, and surgical treatment was indicated.

A

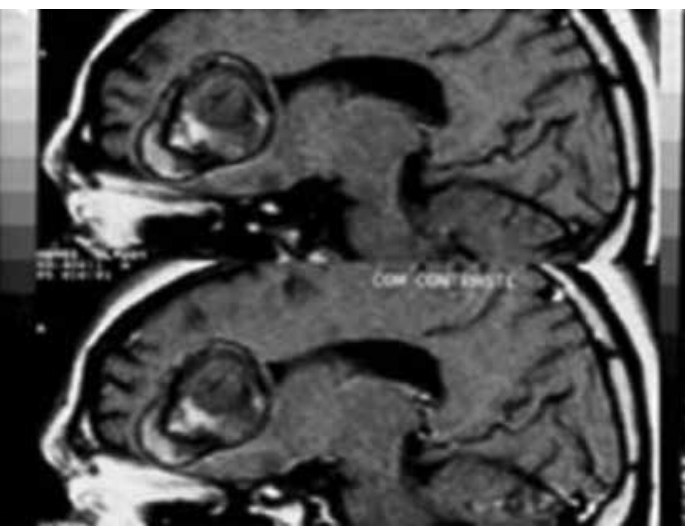

B

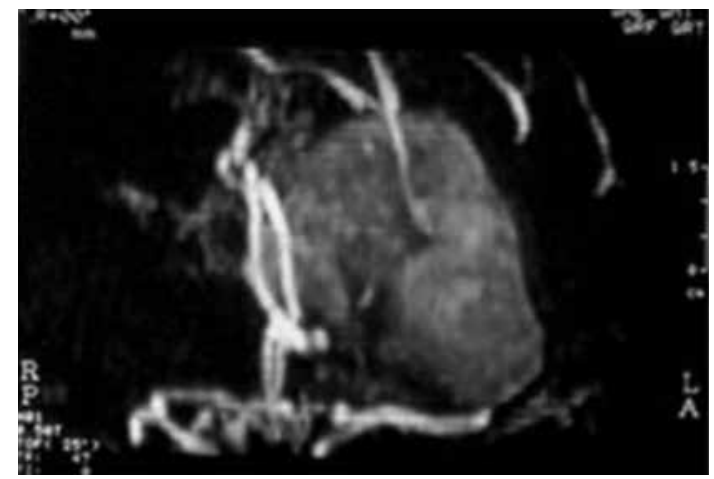

C

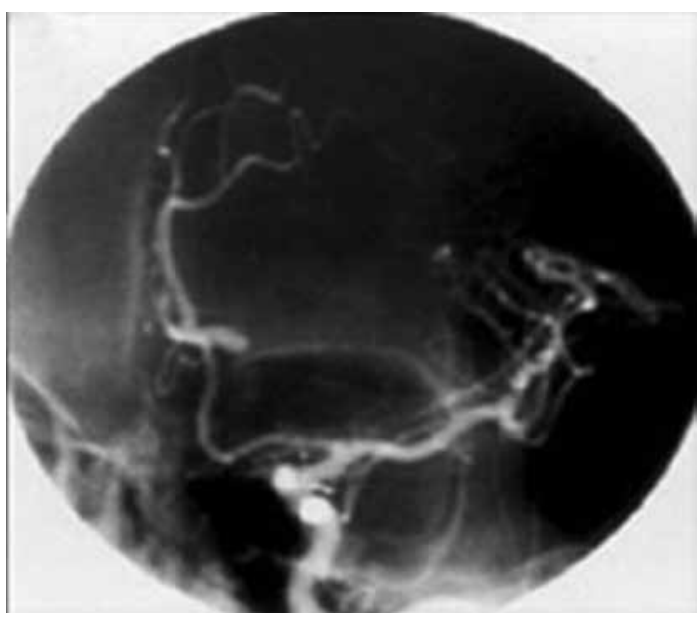

Figure 2 - (A) MRI sagital imaging T2 with gadolinium enhancement with small area of flow void between both frontal lobes with the presence of thrombotic material. (B) Angio-MRI showing the relation between the lesion and the pericallosal vessels. (C) Oblique cerebral angiography: the tiny area of the aneurysm with blood flow is well seen near its neck. 
A bifrontal craniotomy was performed. After interhemispheric approach and ligation of the most anterior part of the superior sagital sinus, both pericallosal arteries distally to the lesion were exposed. There was no evidence of previous bleeding. At this time, it was not possible to obtain proximal control of the afferent artery and, since the aneurysm adhered to the medial surfaces of the frontal lobes and covered the anterior cerebral arteries, the lesion was opened through its dome (Figure 3). Cautious thrombectomy followed by progressive resection of the aneurysmatic sac were performed. This procedure allowed the visualization of the narrow and calcified aneurysm neck between both pericallosal arteries and left calloso marginal artery. At this moment, profuse bleeding started. The left pericallosal artery was temporary clipped, under pharmacological-protection, and the aneurysm neck was dissected and closed with two clips, one of them was applied across the blade of the other, in other to reinforce it.

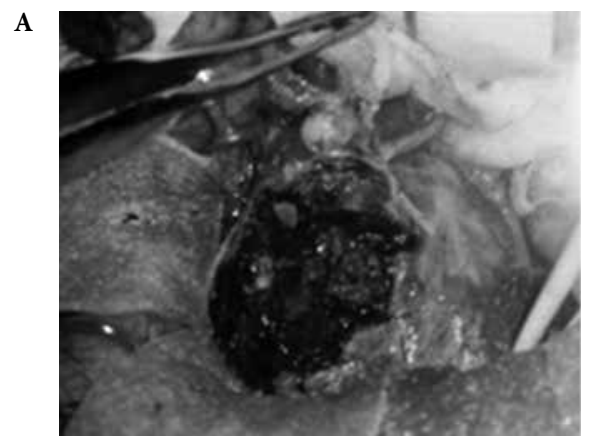

B
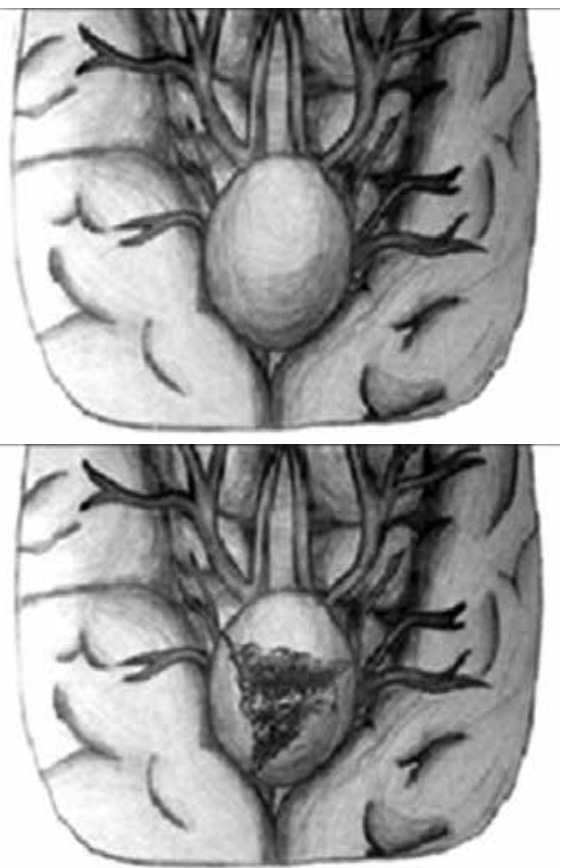

Figure 3 - (A) Operative view, after interhemispheric approach, of the opened aneurysm sac full of thrombotic material. (B) Illustration demonstrating the aneurysm sac before and after its opening.
During the first four postoperative days the patient was drowsy and subsequent recovery was uneventful. The patient was discharged fourteen days after surgery. Motor and cognitive functions slowly improved, with complete recovery over the third postoperative month. Postoperative DCA showed that the lesion neck was successfully clipped, without compromising the blood flow of any cerebral vessel (Figure 4). After one year the patient was asymptomatic, and both general and neurological exams were considered normal.

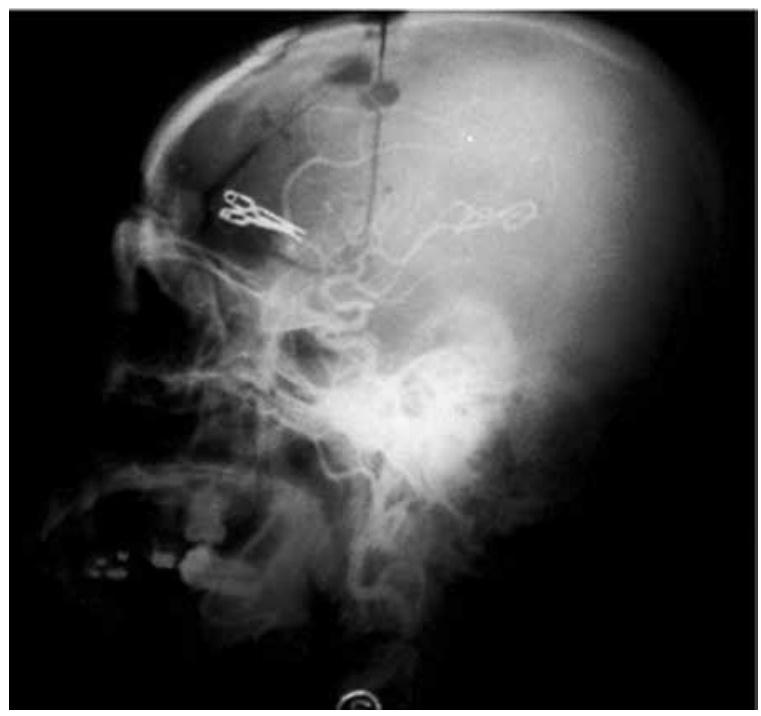

Figure 4 - Postoperative angiography demonstrating good clipping.

\section{Discussion}

Reports of giant $(>2,5 \mathrm{~cm})$ PAA are extremely uncommon in the literature ${ }^{2,3,5,13}$ and are not even mentioned in some series about giant aneurysms. ${ }^{14,15}$ Since Drake's description of a ruptured giant PAA causing SAH in 1979, 33 additional cases have been reported until 2012,,12,16 including this one.

Giant aneurysms are generally proximal in relation to the circle of Willis. Lesions with more than $2,5 \mathrm{~cm}$ are very seldom encountered in distal arteries. ${ }^{15,17}$ The rare incidence of this type of aneurysm may be explained by its tendency to rupture before they become large or giant. ${ }^{18}$ The aneurysmal mass initial swelling may be related to rapid and massive intraluminal thrombosis. ${ }^{5,719}$ Some of these thrombosed aneurysms continue to grow probably because of recurrent hemorrhage into the wall, which allows the lesion's enlargement up to giant sizes..$^{10,20}$ Its clinical presentation usually includes chronic mass signs and symptoms as well as hemorrhage. ${ }^{17,21}$ Bleeding, therefore, occurs in only one third of giant PAA due to their tendency to thrombosis. ${ }^{5}$ In the 
case here reported, the patient presented initially with progressive headaches, seizures and speech alterations developed over a 2-year period, evolving with confusion, paraparesia and bilateral Babinski sign 10 months after the first CT scan.

Image exams, such as CT scan, MRI and cerebral angiography, are of great importance in the assessment of intracranial space-taken lesions. ${ }^{2-4,13,22}$ They enable not only the differential diagnose, but also contributes with the evaluation of intrinsic aspects of aneurysmatic lesions as though its anatomy, the presence of intramural thrombus and the calcification of the aneurysm's sac. ${ }^{4,5,6,8,23}$ Because of those particularities, attention must be paid when evaluating mass effect lesions. CT scan might show rim enhancement due to its calcification, nonenhanced mural thrombus ("target sign") and central enhancement secondary to the residual blood flow. ${ }^{2,3,5,6,10,13,22}$ Due to the presence of thrombosis, the aneurysm might not fill in with contrast under-estimating its size or even leading to the misdiagnose of mass lesions, mainly parafalcine meningiomas, frontal and callosal tumors as well as avascular lesions like abscesses, or might also become indistinguishable from hematomas. ${ }^{1-5,10,13,22}$ Our patient was initially misdiagnosed with a falx cerebri meningioma, based on the first CT scan results. The patient's rapid clinical deterioration within 10 months leaded to a second CT scan that showed a $2 \mathrm{~cm}$ swelling compared to the previous exam. The alternative diagnosis of giant aneurysm was then considered.

Subsequently, the patient was submitted to angioMRI and DCA. Cerebral angiography is essential to diagnose and to investigate origin, size, shape and relations of the lesion with neighbor vessels. On the other hand, giant aneurysms might not be well visualized on angiography due to thrombosis, and also its size may be underestimated when there is partial thrombosis., ${ }^{3,13}$ In the case here presented, DCA allowed the authors to confirm the lesion vascular origin. Maiuri et al. ${ }^{2}$ were the first to report the importance of MRI in giant aneurysm diagnosis. This exam allows the neurosurgeon to distinguish the lesion from other space-occupying lesions of this region, because it shows the blood flow inside the aneurysm and the age of the blood elements. ${ }^{2,5}$ Furthermore, not only MRI is the best exam to demonstrate the relative proportion of the thrombosed area within a giant aneurysm, but also provides additional information about the condition of the surrounding brain. Therefore, it is also essential to accurate diagnosis and provides important data to preoperative planning. . $^{2,13,23}$ This fact was confirmed in the case presented here as angio-MRI helped to show mass effect over the frontal lobes and the aneurysm filling only at its distal neck.

Nine cases out of the twenty reported until 2008 were male (45\%), eight were female (40\%) and in three cases the sex and age were not mentioned (15\%).
In the aforementioned cases, ages ranged between 20 and 81-year-old (mean 49,5-year-old). ${ }^{-17,10,13,17,19,24-26}$

Giant PAA may present special difficulties for the neurosurgeon because of the narrow working space in the interhemispheric fissure and the callosal cistern, dense adhesions to vicinity structures, a broad-based and/or sclerotic neck, difficulty to identify the parent artery and the fixed dome on the pial layer. ${ }^{13}$ Despite those difficulties, surgical treatment continues to be the preferred therapeutic option for giant PAA, with good outcome in the majority of cases reported in the literature. ${ }^{1,13}$

The peculiarity of the case here reported concerns the difficulty of surgical treatment once the surgeon was not able to obtain control of the afferent artery and the aneurysm neck could not be visualized. Also, the aneurysm adhered to the medial surfaces of the frontal lobes and covered the anterior cerebral arteries, so it was necessary to open the aneurysm by its dome to perform a slowly progressive thrombectomy in order to try to collapse the sac.

Another technical aspect, which is worth to mention, is the fact that, even when the thrombotic material had been almost completely excised, the aneurism sac's walls were still fixed to the brain. At this point, clipping could not be performed safely in this condition. In order to work around this situation it was necessary to resect most of the aneurism sac and to apply two clips on a very small, and not as calcified as we could expect in a case like this, aneurism neck. This kind of technical difficulty and this procedure, which had never been reported in the other articles previously published in English language literature for this type of aneurism, was essential to obtain a result that can be classified as successful.

\section{Conclusion}

Giant PAA are extremely rare lesions that might be misdiagnosed. It is necessary careful imaging studies of the lesion and of its relations with adjacent structures, based mainly on MRI and DCA findings, to achieve the correct diagnosis and for surgical planning. It is important to be aware that the aneurism sac of a giant PAA might be thrombosed and/or calcified, therefore, the neurosurgeon must be prepared to proceed its thrombectomy and microsurgical resection of the aneurism's walls in order to make neck clipping safer.

It is also essential to keep in mind that flexible approach is of great importance when dealing with giant aneurysmatic lesions of pericallosal artery due to its variety of intraoperative presentation. In this way, 
microsurgical treatment will have increased chances to succeed.

\section{Conflicts of interest}

The authors declare that there was no conflict of interests in conducting this study.

\section{References}

1. Farias JP, Trindade AM. Giant distal anterior cerebral artery aneurysm not visualized on angiography: case report. Surg Neurol. 1997;48(4):348-51.

2. Maiuri F, Corriero G, D'Amico L, Simonetti L. Giant aneurysm of the pericallosal artery. Neurosurgery. 1990;26(4):703-6.

3. Pozzati E, Nuzzo G, Gaist G. Giant aneurysm of the pericallosal artery. Case report. J Neurosurg. 1982;57(4): 566-9.

4. Preul M, Tampieri D, Leblanc R. Giant aneurysm of the distal anterior cerebral artery: associated with an anterior communicating artery aneurysm and a dural arteriovenous fistula. Surg Neurol. 1992;38(5):347-52.

5. Türe U, Hiçdönmez T, Elmaci I, Peker S. Giant pericallosal artery aneurysm: case report and review of the literature. Neurosurg Rev. 2001;24(2-3):151-5.

6. Koyama S. Giant aneurysm of the pericallosal artery causing acute subdural hematoma--case report. Neurol Med Chir (Tokyo). 2000;40(5):268-71.

7. Park DH, Chung YG, Shin IY, Lee JB, Suh JK, Lee HK. Thrombosed giant aneurysm of the pericallosal artery with inconclusive findings of multiple neuroimaging studies. Neurol Med Chir (Tokyo). 2008;48(1):26-9.

8. de Sousa AA, Dantas FL, de Cardoso GT, Costa BS. Distal anterior cerebral artery aneurysms. Surg Neurol. 1999;52(2):128-35.

9. Hernesniemi J, Tapaninaho A, Vapalahti M, Niskanen M, Kari A, Luukkonen M. Saccular aneurysms of the distal anterior cerebral artery and its branches. Neurosurgery. 1992;31(6):994-8.

10. Nitta T, Nakajima K, Maeda M, Ishii S. Completely thrombosed giant aneurysm of the pericallosal artery: case report. J Comput Tomogr. 1987;11(2):140-3.

11. Wakabayashi $\mathrm{Y}$, Nakano T, Isono M, Shimomura T, Hori S. Dissecting aneurysm of the anterior cerebral artery requiring surgical treatment--case report. Neurol Med Chir (Tokyo). 2000;40(12):624-7.

12. Gelfenbeyn M, Natarajan SK, Sekhar LN. Large distal anterior cerebral artery aneurysm treated with resection and interposition graft: case report. Neurosurgery. 2009;64(5):E1008-9.

13. Topsakal C, Ozveren MF, Erol FS, Cihangiroglu M, Cetin $\mathrm{H}$. Giant aneurysm of the azygos pericallosal artery: case report and review of the literature. Surg Neurol. 2003;60(6):524-33.

14. Hosobuchi Y. Direct surgical treatment of giant intracranial aneurysms. J Neurosurg. 1979;51(6):743-56.

15. Sundt TM Jr, Piepgras DG. Surgical approach to giant intracranial aneurysms. Operative experience with 80 cases. J Neurosurg. 1979;51(6):731-42.

16. Matsushima K, Kawashima M, Suzuyama K, Takase Y, Takao T, Matsushima T. Thrombosed giant aneurysm of the distal anterior cerebral artery treated with aneurysm resection and proximal pericallosal artery-callosomarginal artery end-to-end anastomosis: Case report and review of the literature. Surg Neurol Int. 2011;2:135.

17. Drake CG. Giant intracranial aneurysms: experience with surgical treatment in 174 patients. Clin Neurosurg. 1979;26:12-95.

18. Sindou M, Pelissou-Guyotat I, Mertens P, Keravel Y, Athayde AA. Pericallosal aneurysms. Surg Neurol. 1988;30(6):43440.

19. Hayashi M, Kobayashi H, Kawano H, Handa Y, Kabuto M. Giant aneurysm of an azygos anterior cerebral artery: report of two cases and review of the literature. Neurosurgery. 1985;17(2):341-4.

20. Kaneko T, Nomura M, Yamashima T, Suzuki M, Yamashita J. Serial neuroimaging of a growing thrombosed giant aneurysm of the distal anterior cerebral artery - Case report. Neurol Med Chir (Tokyo). 2001;41(1):33-6.

21. Kanemoto $\mathrm{Y}$, Tanaka Y, Nonaka M, Hironaka Y. Giant aneurysm of the azygos anterior cerebral artery - Case report. Neurol Med Chir (Tokyo). 2000;40(9):472-5.

22. O'Neill M, Hope T, Thomson G. Giant intracranial aneurysms: diagnosis with special reference to computerised tomography. Clin Radiol. 1980;31(1):27-39.

23. Mori T, Fujimoto M, Shimada K, Shin H, Sakakibara T, Yamaki T. Kissing aneurysms of distal anterior cerebral arteries demonstrated by magnetic resonance angiography. Surg Neurol. 1995;43(5):497-9.

24. Lawton MT, Quiñones-Hinojosa A. Double reimplantation technique to reconstruct arterial bifurcations with giant aneurysms. Neurosurgery. 2006;58(4 Suppl 2):ONS-347-53.

25. Pia HW, Zierski J. Giant cerebral aneurysms. Neurosurg Rev. 1982;5(4):117-48.

26. Smith RR, Parent AD. End-to-end anastomosis of the anterior cerebral artery after excision of a giant aneurysm. Case report. J Neurosurg. 1982;56(4):577-80.

Correspondence address

José Fernando Guedes Corrêa

Jardim Botânico Street, 700, Office: 407

22461-000 - Rio de Janeiro, RJ, Brazil

Telephone: (55 21) 2511-4650

E-mail: maristellareis@gmail.com 